\title{
Agro-economics in the Brazilian Legal Amazon: an application of mathematical programming for rural development
}

\author{
Marcus Vinicius Alves Finco* \\ Werner Doppler
}

\begin{abstract}
Biofuel production has been a greatly discussed topic in Brazil. In 2004, these debates led the country to develop new policies and implement a national program for biodiesel use and production (PNPB) with the intent to foster a sustainable rural development. In this context, the present study aims to assess the impacts of the PNPB on rural development in the Brazilian Legal Amazon, in a region of transition between Savannah and Amazon Rainforest. Ranges of socio-economic indicators were collected among smallholders who cultivate Jatropha curcas and Ricinus communis and a linear programming model (LP) was applied at the farm level to simulate strategies and scenarios for the adoption of oil seed activity by farmers and, therefore, the impacts on farm and family income. For this purpose, the software GAMS (General Algebraic Modeling System) was used to support the modeling simulations.
\end{abstract}

Keywords: Agro-economics. Brazilian Amazon. Rural development

* PhD in Agricultural Economics (University Hohenheim, Germany). Professor at Federal University of Tocantins, Brazil. Email: marcus.finco@gmail.com

** Professor at Institute of Agricultural Economics (University Hohenheim, Germany). Email: doppler@uni-hohenheim.de

http://dx.doi.org/10.5335/rtee.v0i41.3733

Submissão: 07/04/2013. Aceite: 19/08/2013 


\section{Introduction}

Global concern for the degradation and exhaustion of natural resources has led governments and scientists around the world to identify alternatives and solutions to the problem. Hayes and Nadkarni (2001) and Alier (2002), for instance, point out that this environmental problem occurs both in developed, as well as in developing countries, in the urban as well as rural spaces, and are mainly a consequence of the pressure due to the current consumption and production patterns. In this context, since the beginning of $21^{\text {st }}$ century an international debate has taken shape, which is currently discussed at 10 out of 10 meetings on sustainable development around the world: pros and cons of biofuels (DUBOIS, 2008; FAO, 2008a; FAO, 2008c).

Regarding the pros, biofuels can shift the energy matrix of a country with the usage of clean and renewable energy. Based on this, biofuels can also bring along positive externalities like the maintenance and provision of environmental services, such as carbon sequestration and reduction of carbon emission (FAO, 2008e). From the socio-economic point of view, biofuels can positively impact rural development and diversify utilization of the local environment. For example, enhancing rural space multi-functionality, where farms are used not only for crop production, but also for eco and rural tourism and, of course, generating strategies that reduce and alleviate poverty, so-called 'pro-poor' strategies (UN Energy, 2007; FAO, 2008b; FAO, 2008d).

Despite of the numerous advantages, some questions have been raised regarding the possible negative externalities generated by biofuel production. These include the decrease in local food production and supply, as well as negative impacts on environmental services and climate change (FAO, 2008a). Regarding the issue of food supply, for instance, the main concern is that biofuels may compete with food crops. This competition for land becomes an issue especially when some of the crops (e.g. maize and rice), which are currently cultivated for food and feed, are redirected towards the production of biofuels. As food-oriented agricultural land is converted to biofuel production, significant negative impacts on food security can be observed, the so-called "food versus fuel" debate (FAO, 2008e; PINGALI et al., 2008; COTULA et al., 2008).

Therefore, in 2004, Brazil launched a biodiesel program, the National program of biodiesel use and production (PNPB), which is based on a scenario of high oil prices, a growing demand for fuels from renewable sources and the country's comparative advantage in natural resources (NASS et al., 2007). The PNPB is an 
Interdepartmental program of the Brazilian government and has several specific targets, such as fostering rural as well as regional development (PNPB, 2005).

In this context, the main objective of the study is to develop and model future scenarios based on the characteristics of family farmers who produce Jatropha curcas (well known as pinhão manso in Brazil), as well as Ricinus communis (well known as mamona in Brazil) seeds vis-à-vis the Brazilian program of biodiesel use and production (PNPB). Therefore, the study aims to discuss the underlying theories regarding the biodiesel program scenarios considering, for instance, the impacts of oil seed activity on income generation and also on the supply of raw/primary material towards biodiesel production. These proposed scenarios are tested at the farm level, and they focus mainly on the integration of farmers into the biodiesel chain, enabling them to improve their income and also enabling the national government to fulfill some of the PNPB main targets, such as income generation, and social inclusion.

So, regarding the main objective described hitherto, mathematical optimization problems can be considered a suitable methodology for this purpose since it seeks, above all, to understand the diversity of responses from different scenarios' simulation (UMSTÄTTER, 1999). Based on that, linear programming (LP) models are stated and modeled to simulate the current status of farming systems. After validating the models in the real/current situation, different scenarios under the umbrella of the PNPB are tested to show the impacts on resource availability and use, as well as the economic success of family farmers. The focus hereby is placed on a combination of measures, which would lead to the integration of family farmers into the biodiesel chain.

In addition, a set of alternatives or possibilities are designed for the different farming systems in order to maintain and improve their income along with the adoption of oil seed activity. The scenarios selected, which are based on the principles of the PNPB, should fulfill some ideal qualities at farm level, such as the non-negative impacts on deforestation of native forests, for instance.

\section{Research area}

The research was carried out in Tocantins State in northern Brazil, a region well known as Brazilian Legal Amazon. The State is situated in a transition area, presenting climate and vegetation from Amazon rain forest (15\% of the territory) and Cerrado (85\% of the territory). This transition area, so-called Ecotone zone, is the home to traditional communities and comprises rich biodiversity, which is 
responsible for numerous environmental services. For this reason, scientific studies and research in the area are extremely important. Often they are focused on understanding the different farming systems and their connections to the local economy and the very diverse environment.

Data collection necessary to create the database was formed through a comprehensive survey, which was carried out between April and September 2008 in two sub-study regions within the Tocantins State. In one sub-study region, Ricinus communis oil seed is cultivated and in the other sub study-region Jatropha curcas is cultivated.

Specific questionnaires were applied to smallholders, who were randomly selected: 27 in the case of Jatropha curcas producers; 24 in the case of Jatropha curcas non-producers; 25 in the case of Ricinus communis producers; and 25 in the case of Ricinus communis non-producers. The selection of smallholders followed statistical procedures; the sample can be considered representative since it comprises more than $90 \%$ of small-scale oil seed producers in the region in question at the time the research was carried out.

\section{Methodological aspects}

\subsection{Model concept}

In the present study, one model was established, which deals with small-scale farming systems and includes a farm, a household, as well as off-farm activities. Therefore, the objective is to maximize the family income, while the impact of different scenarios is determined by the results of model applications under "with and without" scenario development. The differences between future development scenarios, which comprise different biodiesel policies (such as the price of raw/primary material; and the oil seed productivity) - and without them - are the impact of the tested scenarios.

Based on this, the model concept can be explained in five steps, each of which are applied to test the impacts of different biodiesel policy scenarios on a family, as well as farm income: (1) construction of the basic models to describe the farming systems (4 farming systems at small-scale level). The description includes the availability and use of family resources, farm activities, and parameters reflecting economic success, such as farm and family income. The parameters in this model are the average values for the farmers in each farming systems; (2) validation of the model by verification between the models results and the empirical data from 
the survey analyses. Resource availability, level of use, farm activities and economic success are used as parameters for validation; (3) calibration of the model to achieve the highest possible level of model fit (ability to reflect the real situation); (4) application to different biodiesel policy scenarios; and (5) comparing the basic model with the results of the scenario models. The difference between them is the impact of the several scenarios.

\subsection{Linear Programming}

Mathematical programming models are widely used in agricultural economics, as well as in policy analysis (FERNANDES, 2013; OLAJIDE \& DOPPLER, 2012; ABU SHABAN, 2007). They can be constructed from a minimal data set and the constraint structure inherent in programming models is well suited to characterize resource, environmental and policy constraints. In the agricultural field, for instance, a set of inequality constraints, such as those found in farm commodity programs, strongly influences crop and resource allocation. In this context, the most fundamental optimization problem is the linear programming (LP) problem. In the LP problem, decision variables are chosen so that the linear function of the decision variables is optimized and a simultaneous set of linear constraints involving the decision variables is satisfied.

In this context, a LP problem contains several essential elements. First, there are decision variables $\left(X_{j}\right)$, the level of which denotes the amount undertaken of the respective unknowns, of which there are $n(j=1,2 \ldots, n)$. Next is the linear objective function, where the total objective value $(Z)$ equals $c_{1} x_{1}+c_{2} x_{2}+\ldots+c_{n} x_{n}$. Here $c_{j}$ is the contribution of each unit of $X_{j}$ to the objective function. The problem is also subject to constraints of which there are $m$. An algebraic expression for the $i^{\text {th }}$ constraint is $a_{i 1} x_{1}+a_{i 2} x_{2}+\ldots+a_{i n} x_{n} \leq b_{i}(i=1,2, \ldots, m)$, where $b_{i}$ denotes the upper limit or the right hand side imposed by the constraint and $a_{i j}$ is the use of the items in the $i^{t h}$ constraint by one unit of $X_{j}$. Variables $c_{j}, b_{i}$, and $a_{i j}$ represent the LP model data (exogenous parameters).

In addition, LP has proven to be one of the most powerful tools for analysis of resource allocation choices at the farm level (HAZELL \& NORTON, 1986). To be useful a model has to go hand in hand with theory, but it also has to fulfill many practical requirements. It has to be appropriate to the problem and to the available data, it requires an appropriate institutional framework and the economics must be expressed in the model in an appropriate manner. Based on this, models provide a link between economic theory and data, on the one hand, and practical appraisal 
of problems and policy orientations, on the other. Furthermore, LP models can reflect a wide range of economic and institutional behavior. Based on this they might be a powerful tool for analysis. Aiming at formulating the LP mathematically, one should acknowledge the following notations:

$X_{j}=$ the level of the $j^{\text {th }}$ farm activity. Let $n$ denote the number of possible activities, then $j=1$ to $n$;

$c_{\mathrm{j}}=$ the forecasted farm income of a unit of the $j^{\text {th }}$ activity;

$a_{\mathrm{ij}}=$ the quantity of the $i^{\text {th }}$ resource required to produce one unit of the $j^{\text {th }}$ activity. Let $m$ denote the number of resources, then $i=1$ to $m$;

$b_{\mathrm{i}}=$ the amount of the $i^{\text {th }}$ resource available.

With this notation, the LP model can be written as follows:

Such that

$$
\max Z=\sum_{j=1}^{n} c_{j} X_{j}
$$

And

$$
\sum_{j=1}^{n} a_{i j} X_{j} \leq b_{i}, \text { all } i=1 \text { to } m
$$

$$
X_{j} \geq 0, \text { all } j=1 \text { to } n
$$

In other words, the goal is to find the plan (defined by a set of activity levels $X_{\rho} j=1$ to $n$ ) that has the largest possible total $Z$, but which does not violate any of the fixed resource constraints or involve any negative activity levels. This problem is known as the primal LP problem. By convention, this way of presenting a LP model is called Tableau. In this context, the equation to be maximized is called the objective function, where the constraints are called rows and the activities are called columns. Fixed resource supplies, the $b_{i}$ coefficients, are called the right-hand side, or RHS, of the problem. They have all been stipulated as less than or equal $(\leq)$ constraints, although it is possible to include equality constraints (=) or greater than or equal $(\geq$ ) constraints (McCARL \& SPREEN, 2002). 


\subsection{Farm modeling}

A farming system consists of a full range of activities available to the individuals in a particular set of small-scale or large-scale farm units. In this context, household members select from among these options, which are essentially strategies, activities that best contribute to achieving household production targets, in respect to their social reproduction and/or economic success. Thus, a well-designed model reflects these choices by selecting a combination of activities that are feasible given a set of fixed farm constraints that optimize a particular objective while achieving other goals, such as security in food supply, or accessing new markets (HAZELL \& NORTON, 1986).

The main idea behind the process of modeling at the farm level is based on the philosophy that the best way to analyze limited resource farms is to comprehend the relationships and interactions integral to them (McCARL \& SPREEN, 2002). As such, impacts of modified production scenarios are shaped by the constraints on these farming systems. For this reason the issue of farm composition is of immense importance and must be explicitly incorporated in the modeling process (BLAIR, 2007). To deal with such a complex set of factors modeling is undertaken and the LP method is utilized as an appropriate tool. In the first instance, models for the four farming systems attempt to reflect the scenario as closely as possible to the actual one experienced by farmers in these farming systems. The basic model of each farming system describes the group through technical coefficients, resource constraints and a set of activities based on the results of the field surveys carried out in the year of 2008. The results of the model were estimated using the software GAMS (Generalized Algebraic Modeling System) and are presented later on.

\subsubsection{The basic model}

The annual basic model of each farming system was constructed by utilizing the average of each group. This means all parameters in the model represent average figures. The model itself consists of the objective function and constraints and, thus, seeks to capture the main farm activities, which are primarily crop and oil seed production, off-farm activities, labor hiring activities, land hiring activities, household consumption from the farm, household expenditures, credit activities for crop and livestock purposes, sales activities and the resulting annual cash scenario from these activities.

In the first instance a static model will be applied and compared with survey data at a fixed point in time. A comparative static model would then be used to establish a number of scenarios in order to better comprehend the impacts of 
biodiesel policies on the adoption of oil seed activity by farmers and, therefore, the impacts on their farm income. In order to reflect a realistic scenario, very careful attention was paid to the selection of activities captured in the model. A critical balance was calculated between the temptation to include every conceivable activity in the model and the need for an adequately representative model that is not too burdened by a large number of activities, which are possibly insignificant in the context of the observed patterns in the study area (ABU SHABAN, 2007; BLAIR, 2007; REYS, 2003). Therefore, only those activities that are undertaken by each farming system, on average, were selected.

\subsubsection{Objective function}

The role of the objective function herein is to maximize the most significant component of family income in small-scale farming systems, subject to resource availability and other constraints over a period of one year. The family income is maximized through the value of the main agricultural activities found in the average farm, along with off-farm income and production costs. Based on this, the mathematical structure of the static LP model of the present study is presented as follows:

Subject to:

$$
\max Z=\sum_{j=1}^{n} P_{j} X_{j}-C_{j} X_{j}
$$

$$
\begin{aligned}
\sum_{j}^{n} a_{i j} X_{j} \leq b_{i} \quad \forall i \quad & {\left[\pi_{i}\right] } \\
X_{j} \geq 0 \quad \forall j &
\end{aligned}
$$

Where:

$Z$ = the objective function;

$X_{j}=$ the level of activity $j$;

$P_{j}=$ the price per unit of the $j^{\text {th }}$ output activity;

$C_{j}=$ the cost per unit of $j^{\text {th }}$ input;

$n=$ number of activities;

$m=$ number of resources and constraints;

$b_{i}=$ amount of $i^{\text {th }}$ resource available

$a_{i j}=$ technical coefficient (amount of $i^{\text {th }}$ input required to produce one unit of $j^{\text {th }}$ activity)

$\varpi_{i}=$ variable associated with restriction (5), is defined as the shadow price of fixed input $i^{1}$. 
Therefore, the components of the objective function used in the small-scale LP model are as follows: (i) the variable costs of crops and livestock per unit of land and head, respectively, excluding hired labor and hired land costs; (ii) the average sale prices of crops which are used to calculate the revenue of farm products; (iii) household consumption of farm products, which has zero value in the objective function and has been forced in by respective conditions in the right hand side (equation); (iv) hired labor costs are determined by the average wage per man-day observed in the study area; (v) off-farm activities are determined by the average wage (seasonal) and salary (permanent) per man-day as reported by households; and (vi) interest for credit was established as the average interest rate of formal credit (PRONAF) as reported by farming households.

\subsubsection{Constraints}

Constraints on resources are a basic feature of the farming systems. Based on this, constraints on the basic models represent the resource situation of the average farm in each farming system handled in this study. Farmers are supposed to achieve their goals using their limited resources from various activities. Therefore, the different options of production and farm activities contribute to the maximization of the objective function by using these limited resources. In this context, these resource constraints include the following:

- Land: The average arable land area owned by the farmers was used as the upper limit of land constraints. As land in the region in question, is not separated by its type of farm activities, i.e. different farm activities compete for land use, this resource was not divided into different farm activity patterns. The land rented by farmers also had an upper limit according to the survey results.

- Labor: Two sources of labor were identified, and they include family and hired labor. Family labor capacity was calculated using man-equivalent and based on the assumption that the working capacity for one year is 290 days for one family member. The family labor was distributed among farm and off-farm activities and the option to hire labor was restricted by an upper limit.

- Household consumption and household expenditure: Two sources of food supply were considered, i.e. from own farm subsistence and from markets. This shows the interdependence of production and consumption of subsistence and market goods and made it possible for farmers to decide on crop and livestock production through consumption preferences. Food requirements of the 
family are based solely on food products produced on the farm. Constraints relating to other family expenses in the household were also considered.

- Cash balance: It covers the cash coming in and out of the farm and off-farm activities. The in cash flow includes cash coming from selling crops and livestock products and the income from off-farm activities, while the cash out flow includes the costs of crop and livestock production, household expenditure and hiring labor cost.

- Credit: One source of credit considered was formal credit. Informal credit was not included as it was used for other family purposes rather than to be invested in farming.

\subsubsection{Activities}

Family activities are diversified into activities done on farm, off-farm and in the household, regarding small-scale farming systems. Those activities include crop production and selling its products, livestock production and selling its products, household consumption from farm and household expenditures on the market, labor use on farm, off-farm activities and hiring labor.

Oil seed production: Oil seed activity is the main research target of the present study. Families exert the activity in just two of the farming systems at a small-scale level. In this context, the purpose herein is to understand the impacts of biodiesel policies on the adoption of Ricinus communis and Jatropha curcas by those who, so far, have not adopted it. Further, the objective is also to understand the impacts of those policies on family income due to the oil seed activity adoption.

Crop production: Four different crops are cultivated on small-scale farming systems for self-consumption, as well as to be traded at local markets: maize, rice, cassava, and beans. These mentioned crops contribute significantly to the family income and household food consumption.

Livestock production: It is a major farm activity within the four small-scale farming systems. In this context, the livestock represented in the model is cattle because it is the main livestock raised in the region.

Sales and consumption: This involves the selling, purchasing and subsistence consumption activities. Sales and consumption have direct consequences on 
the cash flow to the farm and the family. Further still, they indicate the degree of production in terms of subsistence and market production. The activities assume a perfect demand and supply of crops, livestock and other products. Prices of products are assumed to be the same irrespective of land quality.

Labor activities: Allocation of family labor in farm and off-farm activities is included per activity in one year. Family labor was given in man-day for farm activities. Off-farm activity includes both seasonal and permanent jobs and expressed in man-days per year. The activity of hired labor was also included in the model.

Capital and Household expenditure: One type of credit was considered in the model, the formal one. The interest rate was assumed to be $4.5 \%$ provided by the National Program of Family Agriculture Strengthening (PRONAF). Collateral is needed to obtain such a credit and the interest cost was included in the activities on a yearly basis. Household expenditure was given in aggregated figure for each year.

\subsubsection{Calibration and validation of the model}

The process of model building or rather the theory behind farming systems, as is the case in LP modeling, required validation. In modeling one starts out with assumptions and hypotheses about the farmer's objectives and subjective constraints and bases predictions and prescriptions on them. Validation, therefore, involves the comparison of model predictions with what farmers are actually doing. Wide deviations in the model and reality may indicate that the initial assumptions were wrong and, therefore, require modification. It can be alternatively be concluded that the assumptions were not at all wrong, but that farmers are operating in an inefficient way and it is their management practices that need to be changed. As such, if the model predictions present results similar to the actual state or scenario, it cannot be assumed that the initial assumptions were correct. It is only through testing and validation over a range of circumstances that confidence can be strengthened regarding the results of the model (HELMING, 2005).

Therefore, the first step involved running the model with the actual scenario. The following step required testing based on sensitivity analysis. This sensitivity analysis involved some degree of calibration. The reason for the calibration exercise was to integrate a measure of realism into the model that was absent when the model was left to select freely. It was found, for instance, that households consistently stipulated a minimum amount of land for each crop. When these preferences 
were ignored the model presented highly unrealistic results for the amount of resources available to the households. Integrating these preferences into the model presented much more realistic and acceptable results for the purpose of this study.

Therefore, during the first run of the model free selection between different activities on the available resources was allowed. As expected the model ran towar$\mathrm{ds}$ an overspecialization and, thus, did not select certain crops in different farming systems because no profit is generated from these activities. This outcome does not reflect the real situation for the farmers since they do have part of their production diverted towards self-consumption. Therefore, it was calibrated to represent the real situation in a better way, i.e. selecting certain crop activities regardless of maximizing profit objective.

\section{Results and discussion}

According to Sterman (1988), the output of an optimization model is a description of the best way to accomplish some target. Optimization models do no tell you what will happen in a certain situation, but instead tell you what to do in order to make the best of the situation. On the other hand, the purpose of a simulation model is to portray the real system so that its behavior can be analyzed. So, while optimization models are prescriptive, simulation models are descriptive. Moreover, simulation models do not estimate what should be done to reach a particular target, but instead clarifies what would happen in a given situation. Hence, the purpose of simulations may be to predict how systems might behave in the future under assumed conditions or policy changes. In other words, simulation models are "what if" instruments. With this distinction made, the task of simulating future scenarios is addressed.

\subsection{Scenarios simulation at farm level}

The future impacts of scenarios are analyzed at the family level using a comparative static LP as a tool. The basic model describing the current situation without any scenario is compared to the models of the envisioned scenarios (ABU SHABAN, 2007). The difference between these results can be interpreted as the impact of the scenarios tested. The results, therefore, can be a useful guide in the decision-making processes of the farmers, as well as of decision makers at the policy level. The point herein is that these scenarios focus on the Brazilian program of biodiesel use and production (PNPB), i.e. the goal to understand the impacts at the farm level due to the changes in the national biodiesel policy. In general, two

Teoria e Evidência Econômica - Ano 19, n. 41, p. 48-72, jul./dez. 2013 
major scenarios will be addressed, namely: (1) the impact of the increase in raw/ material price (oil seeds); and (2) the increase in oil seed productivity, per se.

It is important to say that the main concerns of those farmers who cultivate oil seed, and especially of those who do not cultivate it, is about prices and, additionally, the productivity of the vegetable oils. Therefore, the simulation and the scenarios had established aims to foresee what happens to the oil seed activity and, therefore, to the farm income of farmers. In addition, the scenarios also aimed to foresee what happens to the land devoted to the other crops, since oil seed activity in the region usually competes with conventional feedstock for resources.

\subsubsection{Description of scenarios}

As mentioned previously, the scenarios established are based on the Brazilian biodiesel program. In this context, 2 different scenarios were proposed concerning: (1) changes in the productivity of raw/primary material; and (2) changes in the price of raw/primary material (oil seeds). The two scenarios can be considered realistic. In the first scenario, for instance, the productivity of the oil seeds in the region is very low, even lower than the minimum expected by the biodiesel companies. The reasons behind this situation can be explained by: (i) insufficient technical assistance from the biodiesel companies; (ii) delay in the planting period; (iii) low quality of seeds used to cultivate the vegetable oils; and (iv) lack of extension service, for example. Thus, the first scenario and the second scenario were separated into scenario $1 \mathrm{a}$ and scenario $1 \mathrm{~b}$, as well as scenario $2 \mathrm{a}$ and scenario $2 \mathrm{~b}$, respectively.

Scenario 1a: This scenario considers the current price of raw/primary material, i.e. $\mathrm{R} \$ 0.75$ per $\mathrm{kg}$ of seeds in the case of Ricinus communis and $\mathrm{R} \$ 0.35$ per $\mathrm{kg}$ of seeds in the case of Jatropha curcas. In addition, this scenario considers the minimum productivity expected by the biodiesel companies, i.e. $600 \mathrm{~kg}$ per hectare in the case of Ricinus communis production and $2444 \mathrm{~kg}$ per hectare in the case of Jatropha curcas production. It is important to mention that the Jatropha productivity was considered for the whole ten-year contract period, i.e. the average of productivity during 10 years was taken into account.

Scenario $1 b$ : This scenario considers the current price of raw/primary material, also mentioned in scenario 1a, but productivity above the minimum expected by the biodiesel company per hectare. Therefore, $1200 \mathrm{~kg}$ per hectare in the case of Ricinus communis production and $3476 \mathrm{~kg}$ per hectare in the case of Jatropha curcas production. As in scenario 1a, the Jatropha activity was considered for the whole ten-year contract period and, thus, the average of productivity during 10 years was taken into account. 
The second scenario considers the fact that the national government aims to increase the biodiesel blend into fossil diesel (at the moment 5\%, or B5) to B10 until 2015. Since a $1 \%$ increase in the biodiesel blend corresponds to roughly 450 millions of liters of biodiesel, one can be assured that the demand for raw/primary material will increase. However, considering that the supply elasticity of oil seeds is inelastic in the short run (VARIAN, 2006) one can expect a rise in the prices of raw/primary material. Based on this:

- Scenario 2a: This scenario considers a $25 \%$ increase in the price of oil seeds per kg, compared to the current price (mentioned on scenario 1a). In addition, this scenario considers the minimum productivity expected by the biodiesel companies (mentioned on scenario 1a).

- Scenario 2b: This scenario considers a $50 \%$ increase in the price of oil seeds per kg, compared to the current price (mentioned on scenario 1a), and the minimum productivity expected by the biodiesel companies (mentioned on scenario 1a).

In addition, a combined or optimistic scenario was also established, where a $50 \%$ increase in the price of oil seeds, compared to the current price (mentioned on scenario 1a), and productivity above the minimum expected by the biodiesel company (mentioned on scenario $1 b$ ) was input.

\subsubsection{Results of scenarios simulation at farm level}

The results from the different scenario simulations can be seen in the forthcoming Tables 3 and 4. It is important to remember that the basic model, labeled "without scenario" in the following tables, was previously estimated as the baseline scenario and was calibrated with the aim of representing the real situation of the farming systems. Therefore, in the case of oil seed production the calibration allowed the model to present the real area diverted to this activity, as farmers have to produce oil seeds to the biodiesel companies.

However, in the scenario simulations the area for oil seed activity is free to compete for land and other resources with the remaining conventional crops, such as maize, rice, cassava and bean. This situation reflects the reality according to farmers' decisions because they have to decide where to apply the limited resources. So, first an analysis of resource allocation was done, regarding the resource land. Thereafter, the farm and family income was assessed with the aim of identifying whether and in which direction the biodiesel policy is impacting the economic success of farmers. 
Ricinus communis producers: One can notice in scenario 1a that the land devoted to oil seed activity diminished compared to the basic model. So, remaining at the current price of oil seed per $\mathrm{kg}(\mathrm{R} \$ 0.75)$ even as the productivity of Ricinus reaches the minimum expected by the biodiesel company, the farmers prefer to invest in maize production rather than in Ricinus. Different results, however, can be seen in scenario $1 \mathrm{~b}$. Now, although price of oil seed per kg is the same as established in scenario 1a, the productivity of oil seeds per hectare is above the minimum expected by the biodiesel company, i.e. $1200 \mathrm{~kg} / \mathrm{ha}$. In this case, the area diverted to oil seed activity reaches 4 hectares; a figure considerably higher than the basic model ( 2 hectares). The farmers chose, therefore, to invest in oil seed activity rather than invest in conventional feedstock, such as maize, cassava and bean.

However, when the productivity of Ricinus remains at the minimum level expected by the biodiesel company ( $600 \mathrm{~kg}$ per hectare) and the price of oil seed per $\mathrm{kg}$ changes, an increase of $25 \%$ compared to the basic model, the farmers still increase the investment in Ricinus communis activity compared to the basic model. In the scenario 2a, 3.7 hectares are devoted to vegetable oil. Nevertheless, 0.3 hectare is still devoted to cassava production, which was not seen in scenario $1 b$, for example. When productivity remains as expected by the biodiesel company, but the price of oil seed per $\mathrm{kg}$ rises by $50 \%$ compared to the basic model 4 hectares are diverted to Ricinus production and only 0.6 hectares to the production of rice (scenario 2b). Similar results can be seen regarding the combined scenario, or the optimistic scenario, where price is increased by $50 \%$ and the productivity is above the minimum expected by the biodiesel company.

Based on the results, it is clear that the oil seed activity, in the case of Ricinus communis producers, compete with other conventional crops for land and all the financial resources embedded in farm activities. Similar results were found by Finco and Doppler (2010a; 2010b), Finco and Finco (2011). Regarding the farm and family income, for instance, one can observe that, whatever the scenario selected, both incomes are higher when compared to the basic model. Nevertheless, scenario $1 \mathrm{~b}$, where the productivity is above the minimum expected and the price remains the same as in the basic model, shows the highest farm and family income compared to the other scenarios (except in the case of the optimistic scenario). Therefore, the biodiesel policy, in the case of Ricinus communis producers, should focus on the quality of seeds, technical assistance and extension service rather than price, and aim to guarantee the supply of raw/primary material for biodiesel production and at the same time the economic success of farmers. 
Ricinus communis non-producers: In the case of Ricinus non-producers, the scenario simulations seek to include farmers in the biodiesel chain through the adoption of the oil seed activity. So, the scenarios express under which conditions these farmers most probably engage in the activity. Thus, based on the simulations, one can notice that in scenario 1a no land is devoted to Ricinus activity. Remaining at the current price of oil seed per $\mathrm{kg}(\mathrm{R} \$ 0.75)$, even if the productivity of Ricinus reaches the minimum expected by the biodiesel company, the farmers prefer to invest in conventional crops, such as maize, rice, cassava and bean rather than in the oil seed activity. Different results, however, can be seen in scenario 1b. Now, although price of oil seed per $\mathrm{kg}$ is the same established in scenario 1a, the productivity of oil seeds per hectare is above the minimum expected by the biodiesel company, i.e. $1200 \mathrm{~kg} / \mathrm{ha}$. In this case, the area diverted to oil seed activity reaches 1.9 hectare. The farmers chose, therefore, to invest in oil seed activity rather than in other crops, even though 0.5 hectares are devoted to maize production.

However, when the productivity of Ricinus remains at the minimum level expected by the biodiesel company (600 kg per hectare) and the price of oil seed per kg changes, in this case an increase of $25 \%$ compared to the basic model, the farmers reduce their investment in Ricinus communis activity compared with scenario $1 \mathrm{~b}$. In scenario $2 \mathrm{a}$, only 1 hectare is devoted to vegetable oil. In scenario $3 \mathrm{a}$, when the productivity remains as expected by the biodiesel company, but the price of oil seed per kg raises 50\% compared to the basic model, 1.9 hectare is diverted to Ricinus production and only 0.5 hectare to maize production. Similar results can be seen regarding the combined scenario, or the optimistic scenario, where the price is increased in $50 \%$ and the productivity is above the minimum expected by the biodiesel company.

As in the case of Ricinus communis non-producers, the oil seed activity also competes with other conventional crops for land and all the financial resources embedded in farm activities. Similar trend found by Finco and Doppler (2010a). Regarding the farm and family income, one can observe that in scenario 1a they are the same as in the basic model, since no oil seed activity is conducted. However, simulations for the other scenarios present higher farm and family incomes when compared to the basic model. Nevertheless, scenario $1 \mathrm{~b}$, where the productivity is above the minimum expected and the price remains the same as in the basic model, shows the highest farm and family income compared to the other scenarios (except in the case of combined scenario). Therefore, the national biodiesel policy, in the case of Ricinus communis non-producers, as with the case of Ricinus communis producers, should also focus on the quality of seeds, technical assistance and extension service rather than on the price of oil seeds and aim to guarantee the raw/ primary material supply, while at the same time the economic success of farmers.

Teoria e Evidência Econômica - Ano 19, n. 41, p. 48-72, jul./dez. 2013 
As the price of oil seed per kg tends to rise in the country due to the increasing demand for biodiesel in Brazil and at the same time due to the inelastic supply of raw/primary material in the short run, the optimistic scenario (combined scenario), in both Ricinus communis producers and the Ricinus comumunis non-producers case, reflects an realistic situation where a high oil seed productivity is reached and price rises in comparison to the basic model. Herein, the results show that the farm and family income are considerably higher when compared to the basic model. Therefore, if the combined scenario becomes a reality (which is conceivable), one can be assured that the PNPB targets of social inclusion, income generation, and supply of raw/primary material will be accomplished.

Table 1. Farm modeling simulation for Ricinus communis producers and non-producers

\begin{tabular}{l|c|c|c|c|c|c}
\hline \multirow{2}{*}{\multicolumn{1}{c|}{ Activities }} & \multicolumn{7}{c}{ Ricinus communis producers } \\
\cline { 2 - 7 } & Without & Scenario & Scenario & Scenario & Scenario & Comb. \\
& scenarios & $1 \mathrm{a}$ & $1 \mathrm{~b}$ & $2 \mathrm{a}$ & $2 \mathrm{~b}$ & scenario \\
\hline Cultiv. land (ha) & 4.6 & 4.6 & 4.6 & 4.6 & 4.6 & 4.6 \\
Maize (ha) & 1.6 & 2.5 & - & - & - & - \\
Rice (ha) & 0.6 & 0.6 & 0.6 & 0.6 & 0.6 & 0.6 \\
Cassava (ha) & 0.3 & 0.3 & - & 0.3 & - & - \\
Bean (ha) & 0.1 & 0.1 & - & - & - & - \\
Oil seed (ha) & 2 & 1.1 & 4 & 3.7 & 4 & 4 \\
Grassland (ha) & 0.6 & 0.6 & 0.6 & 0.6 & 0.6 & 0.6 \\
Labor (MD) & 340 & 360 & 300 & 310 & 300 & 300 \\
Farm income (R\$) & 3708 & 4534 & 5967 & 4790 & 5377 & 8328 \\
Fami. income (R\$) & 9201 & 10027 & 11460 & 10283 & 10870 & 13821 \\
\hline & & \multicolumn{2}{|c}{ Ricinus communis non-producers } & \\
\multicolumn{1}{|c|}{ Activities } & Without & Scenario & Scenario & Scenario & Scenario & Comb. \\
& scenarios & $1 \mathrm{a}$ & $1 \mathrm{~b}$ & $2 \mathrm{a}$ & $2 \mathrm{~b}$ & scenario \\
\hline Cultiv. land (ha) & 2.4 & 2.4 & 2.4 & 2.4 & 2.4 & 2.4 \\
Maize (ha) & 0.6 & 0.6 & 0.5 & 0.5 & 0.5 & 0.5 \\
Rice (ha) & 0.9 & 0.9 & - & - & - & - \\
Cassava (ha) & 0.8 & 0.8 & - & 0.8 & - & - \\
Bean (ha) & 0.1 & 0.1 & - & - & - & - \\
Oil seed (ha) & - & - & 1.9 & 1 & 1.9 & 1.9 \\
Grassland (ha) & 0.8 & 0.8 & 0.8 & 0.8 & 0.8 & 0.8 \\
Labor (MD) & 320 & 320 & 280 & 300 & 280 & 280 \\
Farm income (R\$) & 3877 & 3877 & 4414 & 3924 & 4134 & 5535 \\
Fami. income (R\$) & 10495 & 10495 & 11032 & 10542 & 10752 & 12153 \\
\hline
\end{tabular}

Notes: Scenario 1a: current price and minimum productivity expected; Scenario $1 \mathrm{~b}$ : current price and productivity above minimum expected; Scenario 2a: price $25 \%$ higher and minimum productivity expected; Scenario $2 \mathrm{~b}$ : price $50 \%$ higher and minimum productivity expected; Combined scenario: price $50 \%$ higher and productivity above minimum expected. 
Jatropha curcas producers: One can notice that in scenario 1a, as with Ricinus communis producers, the land devoted to oil seed activity is lower when compared to the basic model. So, maintaining the current price of oil seed per $\mathrm{kg}$ $(\mathrm{R} \$ 0.35)$, even if the productivity of Jatropha reaches the minimum expected by the biodiesel company, i.e. $2444 \mathrm{~kg}$ per hectare, farmers prefer to invest in conventional crops rather than in Jatropha. Different results, however, can be seen in scenario $1 \mathrm{~b}$. Now, although price of oil seed per $\mathrm{kg}$ is the same as that established in scenario 1a, the productivity of oil seeds per hectare is above the minimum expected by the biodiesel company, i.e. $3476 \mathrm{~kg} / \mathrm{ha}$. In this case, the area diverted to oil seed activity is as high as 3.9 hectares; a figure considerably higher than the basic model (2.6 hectares). The farmers chose, in this case, to invest in the oil seed activity rather than invest in conventional crops.

When the productivity of Jatropha remains at the minimum expected by the biodiesel company ( $2444 \mathrm{~kg}$ per hectare) and the price of oil seed per $\mathrm{kg}$ changes, in this case an augment of $25 \%$ compared to the basic model, the farmers still increase the investment in the oil seed activity compared to the basic model. So, in scenario $2 \mathrm{a}, 3.9$ hectares are devoted to vegetable oil. Nevertheless, 0.8 hectare is devoted to rice, 0.6 hectare to cassava, and 0.2 hectare to bean production. When the productivity remains as expected by the biodiesel company, but the price of oil seed per $\mathrm{kg}$ raises $50 \%$ compared to the basic model, 4.7 hectares are diverted to Jatropha production and only 0.8 hectare to the production of rice (scenario $2 \mathrm{~b}$ ).

Similar to that of Ricinus communis producers and non-producers, it is clear that the oil seed activity, in this case Jatropha curcas producers compete with other conventional crops for land and all the financial resources embedded in farm activities. Regarding the farm and family income, for instance, one can observe that whichever scenario is selected both incomes are higher if compared to the basic model. Nevertheless, in scenario $2 \mathrm{~b}$, where the price is $50 \%$ higher compared to the basic model, and the productivity is at the minimum expected by the biodiesel company, the results show the highest farm and family income compared to the other scenarios (except the combined scenario). Therefore, the biodiesel policy, in the case of Jatropha curcas producers and unlike the case of Ricinus communis, should focus on the prices of oil seed rather than on productivity, guaranteeing a raw/primary material supply and at the same time the economic success of farmers. 
Jatropha curcas non-producers: In the case of Jatropha non-producers, the scenario simulations seek to include these farmers in the biodiesel chain through the adoption of the oil seed activity. Thus, the scenarios express the responses under which these farmers would most probably engage in the activity. Thus, one can notice that in scenario 1a the land devoted to oil seed activity slightly increases compared to the basic model. So, remaining at the current price of oil seed per $\mathrm{kg}(\mathrm{R} \$ 0.35)$ and with the productivity of Jatropha lying at the minimum expected by the biodiesel company, the farmers started investing in the oil seed activity. Similar results, but more aggressive, can be seen in scenario $1 \mathrm{~b}$. Now, although the price of oil seed per kg is the same as established in scenario 1a, the productivity of oil seeds per hectare is above the minimum expected by the biodiesel company, i.e. $3476 \mathrm{~kg} / \mathrm{ha}$. In this case, the area diverted to oil seed activity reaches 1.5 hectare; a figure considerably higher than the basic model. The farmers chose, in this case, to invest in oil seed activity rather than investing conventional crops. Similar results can be seen in the other scenarios, $2 \mathrm{a}, 2 \mathrm{~b}$ and the combined scenario, where the 1.5 hectares represent Jatropha curcas activity and 0.8 hectare for maize and 0.6 hectare for rice production.

In the case of Jatropha curcas non-producers, the biodiesel policy should focus on oil seed price rather than on the oil seed productivity. Herein, the highest farm and family incomes are generated by increases in the price of Jatropha curcas seeds compared to the basic scenario. Moreover, as the price of oil seed per $\mathrm{kg}$ tends to rise in the country, since the biodiesel demand is increasing in Brazil (and the supply of raw/primary material is inelastic in the short run), the optimistic scenario (combined scenario), in both cases of Jatropha curcas producers and Jatropha curcas non-producers, reflects a realistic situation where a high productivity is attained at the same time as the oil seed price rises. Herein, the farm and family income are considerably higher when compared to the basic model. Therefore, if this scenario becomes a reality, one can be assured that the PNPB targets of social inclusion, income generation, and supply of primary material will most probably be accomplished. 
Table 2. Farm modeling simulation for Jatropha curcas producers and non-producers

\begin{tabular}{|c|c|c|c|c|c|c|}
\hline \multirow[b]{2}{*}{ Activities } & \multicolumn{6}{|c|}{ Jatropha curcas producers } \\
\hline & $\begin{array}{c}\text { Without } \\
\text { scenarios }\end{array}$ & $\begin{array}{c}\text { Scenario } \\
1^{\mathrm{a}}\end{array}$ & $\begin{array}{c}\text { Scenario } \\
1 \mathrm{~b}\end{array}$ & $\begin{array}{c}\text { Scenario } \\
2 a\end{array}$ & $\begin{array}{c}\text { Scenario } \\
2 b\end{array}$ & $\begin{array}{c}\text { Combined } \\
\text { scenario }\end{array}$ \\
\hline $\begin{array}{l}\text { Cultivated land (ha) } \\
\text { Maize (ha) }\end{array}$ & $\begin{array}{l}5.5 \\
1.3\end{array}$ & $\begin{array}{c}5.5 \\
-\end{array}$ & $\begin{array}{c}5.5 \\
-\end{array}$ & $\begin{array}{c}5.5 \\
-\end{array}$ & $\begin{array}{c}5.5 \\
-\end{array}$ & $\begin{array}{c}5.5 \\
-\end{array}$ \\
\hline Rice (ha) & 0.8 & 2.3 & 0.8 & 0.8 & 0.8 & 0.8 \\
\hline Cassava (ha) & 0.6 & 0.6 & 0.6 & 0.6 & - & - \\
\hline Bean (ha) & 0.2 & 0.2 & 0.2 & 0.2 & - & - \\
\hline Oil seed (ha) & 2.6 & 2.4 & 3.9 & 3.9 & 4.7 & 4.7 \\
\hline Grassland (ha) & 4 & 4 & 4 & 4 & 4 & 4 \\
\hline Labor (MD) & 419 & 419 & 419 & 396 & 380 & 380 \\
\hline Farm income $(\mathrm{R} \$)$ & 8259 & 8997 & 9934 & 9955 & 12553 & 16126 \\
\hline Family income $(\mathrm{R} \$)$ & 14311 & 15049 & 15926 & 16007 & 18605 & 22178 \\
\hline \multirow[b]{2}{*}{ Activities } & \multicolumn{6}{|c|}{ Jatropha curcas non-producers } \\
\hline & $\begin{array}{c}\text { Without } \\
\text { scenarios }\end{array}$ & $\begin{array}{c}\text { Scenario } \\
1^{a}\end{array}$ & $\begin{array}{c}\text { Scenario } \\
1 \mathrm{~b}\end{array}$ & $\begin{array}{c}\text { Scenario } \\
2 a\end{array}$ & $\begin{array}{c}\text { Scenario } \\
2 b\end{array}$ & $\begin{array}{c}\text { Combined } \\
\text { scenario }\end{array}$ \\
\hline Cultivated land (ha) & 2.9 & 2.9 & 2.9 & 2.9 & 2.9 & 2.9 \\
\hline Maize (ha) & 0.8 & 0.8 & 0.8 & 0.8 & 0.8 & 0.8 \\
\hline Rice (ha) & 0.8 & 0.6 & 0.6 & 0.6 & 0.6 & 0.6 \\
\hline Cassava (ha) & 1.2 & 1.1 & - & - & - & - \\
\hline Bean (ha) & 0.1 & 0.1 & - & - & - & - \\
\hline Oil seed (ha) & - & 0.3 & 1.5 & 1.5 & 1.5 & 1.5 \\
\hline Grassland (ha) & 0.8 & 0.8 & 0.8 & 0.8 & 0.8 & 0.8 \\
\hline Labor (MD) & 345 & 340 & 315 & 315 & 315 & 315 \\
\hline Farm income $(\mathrm{R} \$)$ & 4370 & 4413 & 4823 & 4831 & 4831 & 6849 \\
\hline Family income $(\mathrm{R} \$)$ & 9484 & 9527 & 9937 & 9945 & 9945 & 11963 \\
\hline
\end{tabular}

Notes: Scenario 1a: current price and minimum productivity expected; Scenario $1 \mathrm{~b}$ : current price and productivity above minimum expected; Scenario 2a: price $25 \%$ higher and minimum productivity expected; Scenario $2 \mathrm{~b}$ : price $50 \%$ higher and minimum productivity expected; Combined scenario: price $50 \%$ higher and productivity above minimum expected.

\section{Final remarks}

Income generation, the supply of raw/primary material towards biodiesel production and the regional development are some of the main PNPB targets, stated by the Brazilian government during the year of 2004 . However, to become a reality those targets need to be comprised by the changes in the current biodiesel policy in the country, i.e. the improvement in the quality of oil seeds and technical assistance to farmers seem to be crucial factors in generating higher yields in the field. In addition, 
prices paid by the biodiesel companies to the farmers for the oil seeds is one of the main complaints by the latter, even suggesting that some of the farmers may cease production in the case that the current price remains constant in the coming years.

Based on this, it is imperative that the Brazilian government focuses on a broader biodiesel policy that aims to overcome these shortcomings. As the results from the scenario simulations demonstrate the economic success of farmers and regional development demands efforts to guarantee the continuation of the oil seed activity and, at the same time, the income and job generation in the region in question. More than that, if the Brazilian government wishes for a successful PNPB public program and to fulfill the targets stated previously, they should also empower local and regional agencies and aim to enable them to foster the regional oil seed activity, i.e. select the proper vegetable oil specie, indicate the proper areas for cultivation (economic-ecological zones), monitor and enforce the contracts between companies and family farmers, etc.

The regional development of one of the poorest regions of the country (northern Brazil) needs special attention. The reality of family farming in northern Brazil illustrates the diversity of the country, and thus, is completely different from other regions. These differences, along with the natural endemic characteristics to the region, make the development of the state of Tocantins a challenge, especially when one talks about biodiesel and oilseed production by family farmers. Only a more critical look at regional differences will allow PNPB to meet its goals of social inclusion and income generation in the field in the context of sustainable development. Based on this, we strongly suggest that other studies be carried out, aimed at better understanding the relationship between family farmers and the Brazilian biodiesel chain. 


\title{
Agro-economia na região da Amazônia legal: uma aplicação da programação matemática para o desenvolvimento rural
}

\author{
Resumo
}

\begin{abstract}
A produção de biocombustíveis tem sido um tema muito discutido no Brasil. Em 2004, esses debates levaram o país a desenvolver novas políticas e implementar um programa nacional de biodiesel (PNPB), com a intenção de promover o desenvolvimento rural sustentável. Nesse contexto, o presente estudo visa a avaliar os impactos do PNPB no desenvolvimento rural na região da Amazônia Legal, numa região de transição entre Cerrado e Floresta Amazônica. Diversos indicadores socioeconômicos foram coletados entre os pequenos agricultores que cultivam pinhão manso e mamona, e um modelo de programação linear (LP) foi aplicado para simular estratégias e cenários para a adoção da atividade de sementes oleaginosas por agricultores e, portanto, os impactos sobre a propriedade e renda familiar. Para esse propósito, o software General Algebraic Modeling System (GAMS ) foi usado para dar suporte às modelagens e simulações.
\end{abstract}

Palavras-chave: Agro-economia, Amazônia Brasileira, Desenvolvimento rural

\section{Agroeconomía en la región de la Amazonia brasileña: una aplicación de la programación matemática para el desarrollo rural}

\section{Resumen}

La producción de biocombustibles es un tema muy discutido en Brasil en los últimos tiempos. En 2004, estos debates incentivaron el gobierno a desarrollar nuevas políticas y a implementar un programa nacional de biodiésel (PNPB) con el objetivo de fomentar el desarrollo rural sostenible. En este contexto, el presente estudio busca evaluar los impactos del PNPB en el desarrollo rural de la región de la Amazonia Legal, una región de transición entre el Cerrado y la Floresta Amazónica. Diferentes indicadores socioeconómicos fueron aplicados a pequeños agricultores que plantan piñón (Jatropha curcas L.) y ricino e introducidos en un modelo de programación lineal (LP) que simula estrategias y escenarios de adopción de la actividad de semillas oleaginosas por los agricultores y que, por lo tanto, reproduce los impactos sobre la propiedad y la renta familiar. Paradar apoyo a la elaboración de modelos y simulaciones, se empleó el programa GAMS (General Algebraic Modeling System).

Palabras clave: Agroeconomía. Amazonia Brasileña, Desarollo Rural 


\section{Nota}

1 The shadow price of a fixed input provides the increase in the objective function if the input could be made less restrictive marginally (HELMING, 2005).

\section{References}

ABU SHABAN, A. A. Socio-Economic Assessment of Using Treated Wastewater in Irrigated Agriculture. In. DOPPLER, W. and BAUER, S. (Eds.) Farming and Rural Systems Economics. v. 88. Weikersheim, Margraf Verlag. 2007.

ALIER, J. M. The Environmentalism of the Poor. University of Witswatersrand. Available at http://www.wrm.org.uy/actors/WSSD/alier.pdf (verified 26 October 2009). 2002.

BAUER, S.; KASNAKOGLU, H. Non-linear programming models for sector and policy analysis. Economic Modelling. 275-290. 1990.

BLAIR, R. A. An Assessment of Agricultural Risk and Diversification on Farming Familie's Living Standard under Fuzzy Conditions. A case from Guyana. In. DOPPLER, W. and BAUER, S. (Eds.) Farming and Rural Systems Economics. v. 90. Weikersheim, Margraf Verlag. 2007.

COTULA, L.; DYER, N.; VERMEULEN, S. Fuelling exclusion? The biofuels bomm and poor people's access to land. Available at http://www.iied.org/pubs/pdfs/12551IIED.pdf (verified 26 October 2009). 2008.

DOPPLER, W. Farming and rural systems approaches. Published Lecture Material. Hohenheim University, Stuttgart, Germany. 2004.

DUBOIS, O. How good enough biofuel governance can help rural livelihoods: making sure that biofuel development works for small farmers and communities. FAO, Rome, Italy. 2008.

FAO (Food and Agriculture Organization of the United Nations). Bioenergy, food security and sustainability - Towards an International Framework. Available at http://www.fao.org/fileadmin/user_upload/foodclimate/HLCdocs/HLC08-inf-3-E.pdf (verified 26 October 2009). FAO, Rome, Italy. 2008a.

FAO (Food and Agriculture Organization of the United Nations). Climate change, bioenergy and food security: civil society and private sector perspectives. Available at http://www.fao.org/fileadmin/user_upload/foodclimate/HLCdocs/HLC08-inf-6-E.pdf (verified 26 October 2009). FAO, Rome, Italy. 2008b.

FAO (Food and Agriculture Organization of the United Nations). Climate change, bioenergy and food security: Options for Decision Makers identified by Expert Meetings. Available at http:// www.fao.org/fileadmin/user_upload/foodclimate/HLCdocs/HLC08-inf-5-E.pdf (verified 26 October 2009). FAO, Rome, Italy. 2008c.

FAO (Food and Agriculture Organization of the United Nations). Bioenergy Policy, Markets and Trade and Food Security. Available at ftp://ftp.fao.org/docrep/fao/meeting/013/ai788e.pdf (verified 26 October 2009). FAO, Rome, Italy. 2008d. 
FAO (Food and Agriculture Organization of the United Nations). The state of food and agriculture. Biofuels: prospects, risks and opportunities. Available at http://www.fao.org/docrep/011/ i0100e/i0100e00.htm (verified 26 October 2009). FAO, Rome, Italy. 2008e.

FERNANDES, M. S. Sistemas de integração lavoura-pecuária e políticas de mudanças climáticas: ensaios de programação linear para o estado do Mato Grosso. Dissertação (Mestrado em ...). Programa de Pós-graduação em Desenvolvimento Regional. Universidade Federal do Tocantins, Brasil. 2013.

FINCO, M. V. A.; FINCO, F. D. B. A. Biodiesel and the regional sustainable development: impact on farm income and food security in northern Brazil. Segurança Alimentar e Nutricional, v. 18. 2011.

FINCO, M. V. A.; DOPPLER, W. Bioenergy and sustainable development: the dilemma of food security and climate change in the Brazilian savannah. Energy for Sustainable Development (Elsevier), v. 14. 2010a.

FINCO, M. V. A.; DOPPLER, W. The Brazilian program of biodiesel and the family farmers: What is the reality of social inclusion target in the Brazilian Savannah? Pesquisa Agropecuária Tropical. v. 40. 2010b.

GAMS software, demo version.

HAYES; A.; NADKARNI, M. V. Poverty, Environment and Development. Studies of four countries in the Asia Pacific Region. Available at http://unesdoc.unesco.org/images/0012/001219/121999e. pdf (verified 26 October 2009). 2001.

HAZELL, P. B. R.; NORTON, R. D. Mathematical programming for economic analysis in agriculture. New York: Macmillan. 1986.

HAZELL, P.; PACHAURI, R.K. Overview. In: HAZELL, P.; PACHAURI, R.K (Eds.) Bioenergy and agriculture: promises and challenges. Focus 14. International Food Policy Research Institute, Washington, DC. 2006.

HELMING, J. F. M. A model of dutsch agriculture based on positive mathematical Programming with regional and environmental applications. Ph.D. thesis, Wageningen Universiteit. 2005.

HOWITT; R. E. 1995. Positive Mathematical Programming. American Journal of Agricultural Economics. 77:329-342.

KITCHAICHAROEN, J. 2003. Socio-Economic Assessement of the Farm Resources and Living Standards of Different Ethnic Groups. A case from Northern Thailand. In. DOPPLER, W. and BAUER, S. (Eds.) Farming and Rural Systems Economics. Vol. 47. Weikersheim, Margraf Verlag.

McCARL, B.A.; SPREEN, T.H. 2002. Applied Mathematical Programming Using Algebraic System, Department of Agricultural Economics, Texas A\&M University. Available at http://agecon2. tamu.edu/people/faculty/mccarl-bruce/books.htm (verified 12 November 2009).

NASS, L.; PEREIRA, P.; ELLIS, D. 2007. Biofuels in Brazil: An Overview. Crop Science, vol. 47. OLAJIDE, O.A.; W. DOPPLER. 2012. Intra-Household roles and decision making in remote and peri-urban farming systems of South East Nigeria. International Journal of Agriculture, volume 4, n. 2.

PINGALI, P.; RANEY, T.; WIEBE, K. 2008. Biofuels and Food Security: Missing the Point. Review of Agricultural Economics, vol. 30, n.3, p.506-516. 
PNPB. 2005. Programa Nacional de Produção e Uso de Biodiesel. www.biodiesel.gov.br/programa.html.

REYS, M. A. Farming and rural systems analyses in forest margins: an application of fuzzy theory. The case of West Tocantins, Brazil. In. DOPPLER, W. and BAUER, S. (Eds.) Farming and Rural Systems Economics. Vol. 48. Weikersheim, Margraf Verlag.

STERMAN, J. D. 1988. Deterministic Chaos in Models of Human Behaviour: Methodological Issues and Experimental Results. System Dynamics Review, 4, 148-178.

UMSTÄTTER, J. 1999. Calibrating Regional Production Model using Positive Mathematical Programming. Ph.D. thesis, Universität Hohenheim. Shaker Verlag Aachen.

UN-Energy. 2007. Sustainable Bioenergy: A Framework for Decision Makers. Available at http:// www.fao.org/docrep/010/a1094e/a1094e00.htm (verified at 26 October 2009).

VARIAN, H. R. 2006. Intermediate microeconomics. A modern approach. Sixth edition. 